\title{
Pengaruh Kelas Kemiringan Lereng dan Penggunaan Lahan terhadap Sifat Fisik Tanah di Kawasan Penyangga Waduk Cirata Kecamatan Cipeundeuy Kabupaten Bandung Barat
}

\author{
Apong Sandrawati1), Ade Setiawan'1), dan Gilang Kesumah'2) \\ 1) Staff Pengajar Fakultas Pertanian, Universitas Padjadjaran. \\ 2) Alumni Program Studi Agroteknologi, Fakultas Pertanian, Universitas Padjadjaran \\ Koresponden : apong.sandrawati@unpad.ac.id
}

\begin{abstract}
Waduk Cirata is one of impormant water reservoir in West Java. This reservoir was used for supporting power plants for Java and Bali's area. It's need more attention to keep the function continuity of Waduk Cirata. Greenbelt area was one of factor determinant for establishment of Waduk Cirata. Landuse change in greenbelt area is a great threat for greenbelt area sustainability, future more to establishment of Waduk Cirata. This research was aimed to study the effect of landuse and slope combination to physical property of soil. The research was conducted in greenbelt area of Waduk Cirata, located in Margalaksana and Nenggeleng Village, Cipeundeuy District, Bandung Barat. The independent variable was three landuse type and two class of slope, so that were six combination variable that repeated four times, so there was 24 land unit. This land unit determined with overlay tools in ArcGIs software. Statistical analysis used for determined the effect and relationship between parameter. Based on analysis data, combination of landuse type and class of slope not influence bulk density, porosity, and permeability value. Rubber plantation with class of slope $8-15 \%$ has higher bulk density $\left(1.24 \mathrm{~g} / \mathrm{cm}^{3}\right)$ and higher porosity (66.7 \%), meanwhile, the higher of permeability $(9.31 \mathrm{~cm} /$ hour) found in cocoa plantation with class of slope 16-25\%.
\end{abstract}

Keywords: greenbelt area, landuse, class of slope, bulk density, porosity, permeability.

\section{PENDAHULUAN}

Waduk Cirata merupakan salah satu waduk yang berperan penting dalam hal penyediaan sumber listrik untuk wilayah Pulau Jawa dan Bali. Tingkat kepadatan penduduk yang terus bertambah dengan angka laju pertumbuhan penduduk 1,2-3,5\% per tahun selama tahun 2000-2010 memberikan dampak terhadap peningkatan kebutuhan sumberdaya lahan di sekitar Waduk Cirata (Badan Pengelola Waduk Cirata, 2012).

Kawasan penyangga merupakan kawasan terbuka yang didominasi oleh tanaman tahunan yang mengelilingi waduk. Kawasan penyangga memiliki fungsi untuk mencegah erosi dan pencemaran sehingga umur waduk dapat berumur panjang (umumnya $>50$ tahun). Tujuan dari penetapan kawasan penyangga di sekitar waduk adalah untuk konservasi ekologi dan kondisi sosiologi sehingga dapat mempertahankan manfaat dari kawasan penyangga yaitu untuk menjaga kelestarian waduk (konservasi tanah dan air) dan perlindungan kualitas air(Noni dkk., 2012).

Kawasan penyangga di sepanjang Waduk Cirata saat ini banyak mengalami gangguan diantaranya adalah perubahan penggunaan lahan oleh masyarakat sekitar untuk dijadikan pemukiman dan lahan pertanian. Perubahan penggunaan lahan yang dilakukan oleh manusia secara langsung maupun tidak langsung dapat menyebabkan perubahan karakteristik tanah, diantaranya bobot isi, porositas dan permeabilitas tanah.

Penggunaan lahan merupakan salah satu faktor yang berpengaruh terhadap erosi. Hal ini terjadi karena perbedaan karakteristik vegetasi, kerapatan kanopi dan ketebalan penutup kanopi. Kanopi yang berlapis dapat menurunkan daya rusak dari tumbukan air hujan terhadap tanah. Penggunaan lahan berpengaruh terhadap sifat-sifat tanah, antara lain bobot isi, kelembaban tanah, $\mathrm{pH}$ dan aktivitas organisme (Jia'en et. al., 2002), permeabilitas, porositas, infiltrasi, perubahan hidrologi, serta erosi tanah (Wu and Tiessen, 2002).

Sifat fisik tanah merupakan salah satu komponen penting yang dapat menentukan produktivitas tanah maupun tanaman. Sifat fisik tanah yang mempengaruhi produktivitas tanaman meliputi bobot isi, porositas dan permeabilitas tanah. Terdapat hubungan yang positif antara sifat fisik tanah, permeabilitas, ruang pori total, pori drainase dan bobot isi 
(Arsyad, 2010). Sifat fisik tanah akan berpengaruh terhadap partumbuhan dan perkembangan tanaman. Akar akan semakin mudah menembus tanah yang menyebabkan pertumbuhan tanaman secara keseluruhan akan semakin cepat dan akan memberikan hasil yang lebih tinggi.

Berdasarkan uraian di atas, penelitian ini diharapkan dapat memberi informasi mengenai seberapa besar kelas kemiringan lereng pada berbagai penggunaan lahan terhadap sifat-sifat fisik tanah, yaitu bobot isi, porositas tanah dan permeabilitas tanah di kawasan penyangga Waduk Cirata yang terletak di Kecamatan Cipeundeuy, Kabupaten Bandung Barat. Hasil penelitian ini diharapkan dapat menjadi rujukan untuk pengelolaan lahan di kawasan waduk tersebut.

\section{BAHAN DAN METODE}

Penelitian ini dilaksanakan pada bulan Mei hingga Juli 2014. Tahapan penelitian terdiri atas persiapan, survey lapangan, analisis laboratorium dan pengolahan data. Survey lapangan dilaksanakan di area kawasan penyangga Waduk Cirata. Analisis laboratorium dilaksanakan di Laboratorium Fisika Tanah dan Kesuburan Tanah Fakultas Pertanian, Universitas Padjadjaran.

Bahan-bahan yang digunakan meliputi peta dasar dan peta tematik dan bahan kimia yang digunakan untuk analisis laboratorium. Peta dasar berupa peta rupa bumi (RBI), peta tematik meliputi: peta penggunaan lahan (update citra landsat tahun 2012), dan peta tanah. Data lain yang digunakan adalah data curah hujan (10 tahun terakhir).

Peralatan penelitian yang digunakan meliputi peralatan kerja lapangan, laboratorium, dan analisis data. Peralatan kerja lapangan meliputi: Global Positioning System (GPS), klinometer, soil munsell colour chart, ring sampler, meteran, pisau/golok, cangkul, plastik, alat tulis dan label nama serta kamera. Peralatan laboratorium meliputi timbangan digital, oven, permeameter, gelas ukur, dan lain-lain. Peralatan yang digunakan untuk analisis data meliputi komputer yang dilengkapi dengan software ArcGIS 10.1 dan SPSS.

Penelitian dilakukan dengan metode survey bebas sistematik, dan analisis data secara deskriptif dan komparatif. Variabel bebas pada penelitian ini adalah kemiringan lereng dan jenis penggunaan lahan. Terdapat 2 (dua) kelas kemiringan lereng dan 3 (tiga) jenis penggunaan lahan, sehingga diperoleh 6 kombinasi variabel bebas (Tabel 1). Kombinasi ini diulang 4 kali sehingga diperoleh 24 satuan analisis.

Tabel 1 Kombinasi Variabel Bebas Penelitian

\begin{tabular}{ccc}
\hline $\begin{array}{c}\text { Unit } \\
\text { Lahan }\end{array}$ & Penggunaan Lahan & $\begin{array}{c}\text { Kelas Kemiringan } \\
\text { Lereng }\end{array}$ \\
\hline A & Tegalan (Jagung) & $8-15 \%$ \\
B & Tegalan (Jagung) & $16-25 \%$ \\
C & Kebun (Kakao) & $8-15 \%$ \\
D & Kebun (Kakao) & $16-25 \%$ \\
E & Kebun (Karet) & $8-15 \%$ \\
F & Kebun (Karet) & $16-25 \%$ \\
\hline
\end{tabular}

Tahap pertama kegiatan penelitian adalah melakukan persiapan. Kegiatan persiapan meliputi: studi literatur, penyusunan peta kerja yang meliputi pembentukkan peta satuan lahan melalui proses overlay peta kemiringan lereng dan peta pengunaan lahan dilakukan dengan bantuan software ArcGIS. Lokasi pengamatan ditentukan berdasarkan peta satuan lahan yang diperoleh, dipilih 24 titik yang paling mewakili. Kegiatan persiapan selanjut-nya adalah survey pendahuluan atau prasurvey. Survey dilakukan terhadap pengecekan akses jalan dan perizinan.

Kegiatan survey utama dilakukan untuk mengamati kondisi di lapangan dan pengambilan contoh tanah. Deskripsi lingkungan meliputi: posisi atau letak, iklim, topografi, elevasi, tingkat erosi, drainase, vegetasi alami dan penggunaan lahan, pengelolaan tanah, dan kondisi air tanah. Pengambilan contoh tanah dilakukan ring sampler.

Contoh tanah yang diperoleh melalui kegiatan survey utama dianalisis di Laboratorium Fisika dan Konservasi Tanah. Analisis dilakukan terhadap nilai bobot isi dan porositas ditetapkan dengan core method, dan permeabilitas tanah diukur dengan permeameter dengan pendekatan hukum Darcy.

Data lapangan dan data hasil analisis laboratorium diukur secara statistik untuk memperoleh hubungan antar parameter. Tahap pertama dalam pengujian statistika adalah uji kenormalan data menggunakan uji Kolmogorov-Smirnov. Tahap selanjutnya adalah analisis sidik ragam yang dilakukan melalui Parametric One Way Analyses of Variance atau uji F. Hasil analisis sidik ragam akan memperlihatkan adanya pengaruh antar 
parameter uji. Jika hasil analisis ragam menunjukkan pengaruh yang nyata, maka analisis dilanjutkan dengan uji lanjut tukey pada taraf nyata $5 \%$. Hasil uji lanjut akan mengidentifikasi seberapa besar perbedaan antara kelas kemiringan lereng dan jenis penggunaan lahan terhadap bobot isi, porositas dan permeabilitas tanah.

\section{HASIL DAN PEMBAHASAN}

\subsection{Kondisi Umum Daerah Penelitian}

Penelitian dilaksanakan di kawasan penyangga Waduk Cirata wilayah Desa Margalaksana dan Desa Nenggeleng, Kecamatan Cipeundeuy, Kabupaten Bandung Barat. Luas areal kajian $\pm 132,03$ ha. Daerah penelitian terletak pada $06^{\circ} 45^{\prime} 00^{\prime \prime}-06^{\circ} 46^{\prime} 30^{\prime \prime} S$ LS dan 107'17'30"- 107²1'00" BT (Gambar 1). Ketinggian tempat berada pada $220-270 \mathrm{~m}$ di atas permukaan laut.

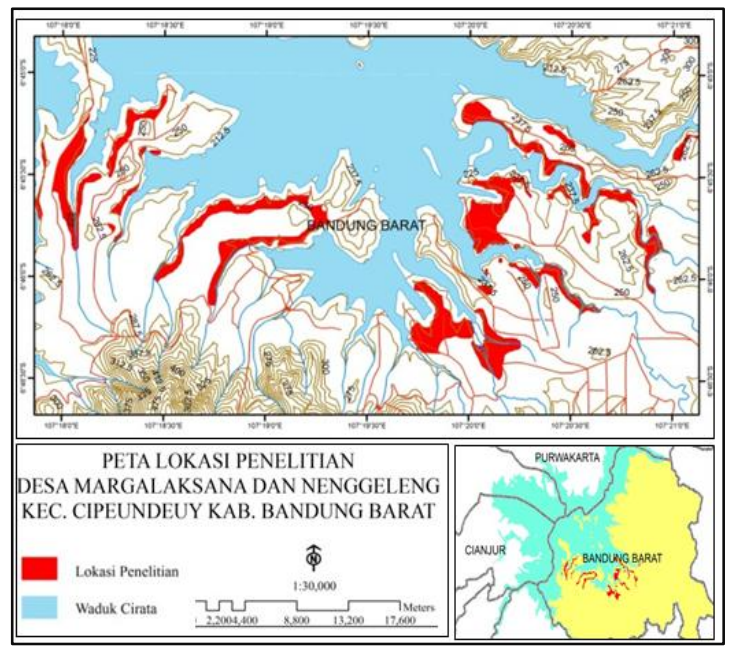

Gambar 1 Lokasi Penelitian

Data curah hujan dalam 10 tahun terakhir diperoleh dari PJB Waduk Cirata. Curah hujan di daerah penelitian berkisar antara 2.000-3.000 mm/tahun. Berdasarkan klasifikasi Schmidt dan Fergusson lokasi penelitian termasuk ke dalam tipe iklim C (agak basah).

Topografi di areal penelitian dapat diklasifikasikan landai (8-15 \%) hingga berbukit atau agak curam (16-25\%). Kelas kemiringan lereng landai (8-15\%) memiliki luas 51,43 ha, sedangkan kelas kemiringan lereng agak curam (16-25\%) memiliki luas 81,60 ha.

Berdasarkan hasil pengamatan lapangan, penggunaan lahan didominasi oleh perkebunan swasta (kebun karet dan kebun kakao), dan tegalan yang sebagian besar ditanami jagung dan palawija. Luas areal perkebunan (PT. Bajabang Indonesia) 49,99 ha (kebun karet) dan 23,75 ha (kebun kakao), sedangkan areal tegalan yang telah dikelola oleh warga sekitar 59,29 Ha.

\subsection{Bobot Isi Tanah}

Hasil uji sidik ragam menunjukkan bahwa kemiringan lereng dan penggunaan lahan tidak berpengaruh nyata terhadap bobot isi tanah (Tabel 2). Namun, berdasarkan pengamatan terhadap nilai bobot isi pada masing-masing perlakuan, dapat diperoleh bahwa pada jenis penggunaan lahan kebun karet nilai rata-rata bobot isi cenderung lebih rendah dibandingkan jenis penggunaan lahan lainnya.

Tabel 2 Pengaruh Penggunaan Lahan dan Kemiringan Lereng Terhadap Bobot Isi Tanah

\begin{tabular}{ccc}
\hline Unit & Kombinasi Variabel & $\begin{array}{c}\text { Bobot Isi } \\
\left(\mathrm{gr} / \mathrm{cm}^{3}\right)\end{array}$ \\
\hline A & Tegalan (Jagung) 8-15\% & 1,24 a \\
B & Tegalan (Jagung) 16-25\% & 1,14 a \\
C & Kebun (Kakao) 8-15\% & 1,18 a \\
D & Kebun (Kakao) 16-25\% & 1,13 a \\
E & Kebun (Karet) 8-15\% & 1,12 a \\
F & Kebun (Karet) 16-25\% & 1,13 a \\
\hline Keterangan: Angka-angka yang diikuti huruf Tukey \\
yang sama menunjukkan tidak berbeda \\
nyata menurut Uji Tukey & pada taraf \\
& nyata 5\%.
\end{tabular}

Hal ini diduga karena pada penggunaan lahan kebun karet mempunyai kerapatan kanopi dan ground cover yang lebih rapat dibandingkan pada penggunaan lahan lainnya. Tanah yang memiliki ground cover rumputrumputan tebal tidak mudah hancur oleh tumbukan air hujan, sehingga tidak terjadi penyumbatan lubang pori tanah. Menurut Hardjowigeno, 2010) tanah yang mempunyai banyak pori makro akan mempunyai nilai bobot isi yang rendah, sebaliknya bila pori makro sedikit akan mempunyai bobot isi yang tinggi.

Jenis penggunaan lahan tegalan pada kemiringan lereng landai $8-15 \%$ cenderung memiliki nilai bobot isi yang lebih tinggi dibandingkan dengan penggunaan lahan kebun karet dan kakao. Pada lahan tegalan tajuk tanaman kurang menutupi permukaan tanah, sehingga kemampuan menahan energi 
kinetik air hujan jatuh ke tanah lebih rendah. Energi kinetik air hujan ini mampu memadatkan tanah melalui proses tumbukan butirbutir air hujan dengan tanah sehingga apabila terjadi pemadatan tanah, maka bobot isi menjadi lebih tinggi (Arsyad, 2010).

\subsection{Porositas Tanah}

Hasil uji sidik ragam menunjukan bahwa kemiringan lereng dan penggunaan lahan tidak berpengaruh nyata terhadap porositas tanah (Tabel 3). Keadaan ini sama dengan nilai bobot isi. Jika diperhatikan nilai porositas pada kelas lereng 16-25\% lebih tinggi dari porositas pada kelas lereng 8-15\%, namun hal ini tidak berlaku pada penggunaan lahan kebun karet.

Tabel 3 Pengaruh Penggunaan Lahan dan Kemiringan Lereng Terhadap Porositas Tanah

\begin{tabular}{ccc}
\hline Unit & Kombinasi Variabel & $\begin{array}{c}\text { Porositas } \\
\left(\mathrm{gr} / \mathrm{cm}^{3} \text { ) }\right.\end{array}$ \\
\hline A & Tegalan (Jagung) 8-15\% & 53,37 a \\
B & Tegalan (Jagung) 16-25\% & 57,02 a \\
C & Kebun (Kakao) 8-15\% & 55,40 a \\
D & Kebun (Kakao) 16-25\% & 57,49 a \\
E & Kebun (Karet) 8-15\% & 66,69 a \\
F & Kebun (Karet) 16-25\% & 57,16 a \\
\hline Keterangan: Angka-angka yang diikuti huruf Tukey \\
\multicolumn{4}{c}{ yang sama menunjukkan tidak berbeda } \\
nyata menurut Uji Tukey pada taraf nyata \\
5\%.
\end{tabular}

Jenis penggunaan lahan kebun karet memiliki nilai porositas yang cenderung tinggi. Hal ini diduga karena pada pengunaan lahan kebun karet memiliki kerapatan kanopi dan ground cover yang lebih rapat dibandingkan pada penggunaan lahan lainnya. Kondisi ini menyebabkan kepadatan tanah pada jenis penggunaan lahan kebun karet meningkat. Semakin padat tanah berarti semakin sulit untuk menyerap air, maka porositas tanah semakin kecil. Semakin mudah tanah menyerap air maka tanah tersebut memiliki porositas yang besar (Hanafiah, 2005).

Jenis penggunaan lahan tegalan memiliki nilai porositas yang cenderung rendah. Hal ini diduga karena tegalan mempunyai penutupan lahan yang sedikit, sehingga daya hancur tanah oleh air hujan semakin besar. Hancurnya lapisan bagian atas oleh air hujan memperbesar nilainya erosi yang mengakibatkan lapisan top soil semakin menipis. Hilangnya top soil akan membuka lapisan tanah bagian bawah. Kandungan liat tanah pada lapisan di bawah top soil biasanya lebih tinggi, sehingga pada bagian permukaan tanah semakin padat (Hardjowigeno, 2010).

\subsection{Permeabilitas Tanah}

Hasil uji sidik ragam menunjukan bahwa kemiringan lereng dan penggunaan lahan tidak berpengaruh nyata terhadap permeabilitas tanah (Tabel 4). Namun, jika dikaji lebih detil, data nilai permeabilitas menunjukkan perbedaan pada setiap kombinasi penggunaan lahan dan kemiringan.

Tabel 4 Pengaruh Penggunaan Lahan dan Kemiringan Lereng Terhadap Permeabilitas Tanah

\begin{tabular}{ccc}
\hline Unit & Kombinasi Variabel & $\begin{array}{c}\text { Permeabilitas } \\
\text { (cm/jam) }\end{array}$ \\
\hline A & Tegalan (Jagung) 8-15\% & 3,80 a \\
B & Tegalan (Jagung) 16-25\% & 7,33 a \\
C & Kebun (Kakao) 8-15\% & 4,52 a \\
D & Kebun (Kakao) 16-25\% & 9,31 a \\
E & Kebun (Karet) 8-15\% & 4,29 a \\
F & Kebun (Karet) 16-25\% & 3,80 a \\
\hline Keterangan: Angka-angka yang diikuti huruf Tukey \\
yang sama menunjukkan tidak berbeda \\
nyata menurut Uji Tukey pada taraf nyata \\
5\%.
\end{tabular}

Nilai permeabilitas tertinggi (paling cepat) terdapat pada kombinasi perlakuan penggunaan lahan kebun kakao pada kemiringan lahan 8- $15 \%$ dengan nilai 9,31 cm/jam. Hal ini diduga oleh jenis penggunaan lahan kebun kakao hanya memiliki serasah daun kakao tanpa adanya tegakan lain sehingga laju air masuk ke dalam tanah cenderung cepat akibat terdapat banyaknya pori tanah. Serasah daun kakao menjadi sumber bahan organik bagi tanah, meskipun proses dekomposisi yang tergolong lambat.

Banyaknya kandungan bahan organik menyebabkan pori tanah lebih banyak pada lapisan top soil (lapisan organik). Serasah daun kakao ini disukai oleh organisme tanah, semakin banyak serasah semakin tinggi aktivitas organisme tanah. Aktivitas organisme seperti cacing tanah akan meningkatkan permeabilitas tanah (Hardjowigeno, 2010) Serasah juga dapat mencegah butiran-butiran air hujan mengenai langsung permukaan ta- 
nah. Proses penghancuran butiran tanah akan memacu pemadatan tanah yang akan mengurangi nilai permeabilitas (Morgan, 1980).

Penggunaan lahan tegalan pada kemiringan lereng $8-15 \%$ dan $16-25 \%$ memiliki nilai permeabilitas yang cenderung rendah. Hal ini diduga pada penggunaan lahan tegalan memiliki kerapatan kanopi yang rendah maka akan memperbesar peluang terjadinya erosi. Lahan dengan kerapatan kanopi yang rendah memungkinkan air hujan akan langsung jatuh ke permukaan tanah dan menghancurkan agregat di permukaan tanah. Penutupan pori tanah dan pemadatan akan menyebabkan permeabilitas lebih lambat (Arsyad, 2010).

\section{SIMPULAN}

Kemiringan lereng dan penggunaan lahan tidak berpengaruh nyata terhadap nilai bobot isi, porositas dan permeabilitas tanah di kawasan penyangga Waduk Cirata. Kebun karet dengan kelas kemiringan 8-15\% memberikan nilai bobot isi terendah $(1,12$ $\mathrm{g} / \mathrm{cm}^{3}$ ) dan porositas tertinggi $(66,7 \%)$. Bobot isi tertinggi $\left(1,24 \mathrm{~g} / \mathrm{cm}^{3}\right)$ terdapat pada lahan tegalan dengan kemiringan lereng 8-15\%. Kebun kakao dengan kelas kemiringan lereng $16-25 \%$ memberikan nilai permeabilitas tanah tertinggi $(9,31 \mathrm{~cm} / \mathrm{jam})$.

\section{DAFTAR PUSTAKA}

Arsyad, S. 2010. Konservasi Tanah dan Air. Institut Pertanian Bogor Press. Bogor.

Badan Pengelola Waduk Cirata. 2012. Master Plan Waduk Cirata. Laporan Kajian. Bandung.

Hanafiah, K. A. 2005. Dasar-Dasar Ilmu Tanah. PT. Raja Grafindo Persada, Jakarta

Hardjowigeno, S. 2010. Ilmu Tanah. Akademika Pressindo, Jakarta

Jia'en, Z, W. Mc Fee, D. Stott and S. Green. 2002. Evaluation of soil health indicators in different land uses. Soil Science Society of American Journal. 63: 88-93.

Morgan, R.P.C. 1980. Soil Erosion and Conservation. Longman Scientific and Techinical, England.

Noni, S dan Suryoko, S. 2012. Partisipasi masyarakat dalam perencanaan sabuk hijau pada Kawasan Waduk Jatibarang. Prosiding Seminar Nasional Pengelolaan Sumberdaya Alam dan Lingkungan, Semarang: 85-90.

Wu, R., and Tiessen, H. 2002. Effect of land use on soil degradation in Alpine grassland soil, China. Soil Science Society of American Journal, 66:1648-1655. 